\title{
Profitability Analysis of Selected Cement Companies in India
}

\author{
Dr Swapan Kumar Pan, Durga Pada Mal \\ (Principal, Guskara Mahavidyalaya), \\ (Associate Professor of Commerce, Deshabandhu Mahavidyalaya, Chittaranjan)
}

\begin{abstract}
The term 'profit' is an accounting concept which shows the excess of income over expenditure viewed during a specified period of time. The basic financial objective of companies is to maximize, within socially acceptable limits, profits from the use of funds employed by them. If an enterprise fails to make profit, capital invested is eroded and if this situation prolongs, the enterprise ceases to exist. Profit can be increased in two ways: by increasing turnover or total income, or by reducing total costs, or total expenditure. In practice, both methods be used to the maximum extent possible. But this is not the only factor of testing financial efficiency of a company. Many companies which appear to be operating satisfactorily come to grief because they neglect cash flow, the day to day expenditure needed to keep them afloat. It is therefore vital that managers, including those concerned with performance, should acquaint themselves with modern practice in this respect and become familiar with the latest ideas on the subject. The term "profitability" is a combination of two words namely profit and ability. To obtain profit, from accounting point of view total expenses are deducted from the total revenues for a given period. The word ability means the earning power of operating performance of the concern on its investment. Therefore, profitability may be defined as the ability of a given investment to earn a return from its use. The paper mainly focuses on analyses of profitability of selected cement companies in India during period of 2001 to 2010.
\end{abstract}

Key Words: Profitability, Cashflow.

\section{Introduction:}

In India, the foundation of a stable cement industry was laid in 1914 when the Indian Cement Company Ltd. manufactured cement at Porbundar in Gujarat. In the initial stages, particularly during the period before Independence, the growth of the sector had been very slow. The indigenous production of cement was not sufficient to meet the entire domestic demand and accordingly, the Government had to control its price and distribution statutorily. Also, the large quantities of cement had to be imported for meeting the deficit in the country. However, with liberalization and introduction of several policy reforms, the cement industry has been decontrolled which gave impetus to its pace of growth. It has made rapid strides both in capacity/ production and process technology terms. Today, it is one of the most advanced and pioneering sectors in the country. Cement is a basic material input which facilitates the promotional fast pace, in the areas of infrastructural set up and other construction related works. Since it is a decontrolled commodity, its production and prices are largely governed by economic factors, like, demand and supply, cost of raw materials and other inputs, production as well as distribution costs and developmental efforts. Cement is an essential component of infrastructure development and most important input of construction industry, particularly in the government's infrastructure and housing programs, which are necessary for the country's socioeconomic growth and development. The Indian cement industry is the second largest producer of cement in the world just behind China, but ahead of the United States and Japan. Also the industry is a significant contributor to the revenue collected by both the central and state governments through excise and sale. The industry occupies an important place in the national economy because of its strong linkages to other sectors such as construction, transportation, coal and power. The most important use of cement is the production of mortar and concrete used by the construction and real estate sectors. The world production of hydraulic cement is dominated by China (1.2 billion by India and Brazil, with these 3 countries contributing to over half of global production). There are a number of employment opportunities within the sector such as site engineer, packaging engineer, surveyor, geologist, contractor, and supervisor amongst others. Typically the industry is characterized by few large players due to the high entry barriers such as economies of scale, high capital requirements, long gestational period of over 3 years and the need for capacity augmentation in large increments. These producers tend to have high bargaining power due to their limited numbers and the lack of any substitutes for their product, which is quintessential for secondary industries. It attracted FDI worth US\$ 3,084.89 million during the year 2000 to 2014. The production capacity is projected to reach 550MT by financial year 2020 . 


\section{Review of Existing Literature}

Several studies have been carried out on various aspect of profitability of corporate sector in India. Some of them which are notable ones are reviewed for the purpose of identifying the research gaps.

Banerjee. (1982) opined in a research work that corporate profitability is influenced by its liquidity in three different manners. Upto a certain level increase in liquidity leads to an increase in profitability, beyond that profitability remains constant with the increase in liquidity upto a certain point and thereafter increase in liquidity leads to decline in profitability.

Banerjee.(1982) in his study on cash management observed that liquidity of a firm was largely affected by the composition of its working capital. The study conformed to the theoretical argument that the higher the proportion of current assets to total assets the higher is the liquidity.

An econometric analysis regarding price cost margin in Indian manufacturing industries was made by Jain (1981) who observed that cost factors were considered as the most significant determinant of profitability.

Mallick and Sur (1998) examined the impact of working capital management on profitability in Indian Tea industry with the help of some statistical tools and techniques. The study revealed that, out of the nine ratios relating to working capital management five ratios registered positive association and the remaining four ratios showed negative correlation with the profitability indicator.

Sur. and Rakhit. (2005) in their research study examined the relationship between assets management and profitability taking into account 25 selected enterprises in Indian corporate sector. The study revealed that receivable turnover ratio was positively associated with profitability in 14 companies, inventory turnover ratio was positively associated with profitability in 10 companies and operating long term asset turnover ratio was positively associated with profitability in 19 out of 25 selected companies. So all the companies did not conform to the traditional view that higher the asset turnover the higher is profitability. Taking all the selected companies as a whole, a positive association between receivable turnover ratio and profitability and between operating long term asset turnover ratio and profitability was found. However a negative relationship between inventory turnover ratio and profitability was noticed.

Chakraborty (2008) evaluated the relationship between working capital and profitability of 25 selected companies in the Indian pharmaceutical industry during the period 1996-97 to 2007-08. The study revealed that the liquidity management, inventory management and credit management made positive contribution towards improvement of the corporate profitability.

Basu. (2011) examined in his study the relationship between debtors management and profitability taking eleven selected companies in Indian cement Industry for the period 2000-2009. The study revealed that current ratio was positively associated with return on capital employed in 7 companies, inventory turnover ratio was positively associated with return on capital employed in 9 companies and debtor turnover ratio was positively associated with return on capital employed in 9 companies.

Sathya. (2012) conducted a study on analysis of composite profitability index of 30cement companies in India. While making this study the researcher used secondary data and analyzed these data by using various statistical tools and techniques. The study showed that in order to rank the selected companies in terms composite profitability, ratio-wise scores were aggregated and the firm securing the highest total score captured the highest rank and the firm securing the lowest total score occupied the last rank.

\section{Objectives of the Study:}

The study has the following objectives:

i. To measure the profitability of the selected companies in the Indian cement industry during the period under study.

ii. To identify the profitability trends of the selected companies during the same period.

iii. To examine the growth of selected cement companies in India.

\section{Scope of the Study:}

In the present study twelve companies in Indian cement industry were covered. It was an attempt to analyze the profitability of the selected companies in the Indian cement industry during the period under study, i.e. from 2001 to 2010 .

\section{(i) Sample design:}

\section{Research Methodology of the Study:}

The study was based on twelve selected companies in Indian cement industry. In this study purposive sampling procedure was followed. The selected twelve companies were:

1. ACC

2. Ambuja

3. Birla 
4. Century

5. Chettiland

6. Grasim

7. India

8. Madras

9. OCL

10. Shree

11. Sanghi

12. Prism

(ii) Collection of data:

The data of the selected twelve companies in Indian cement industry for the period 2001 to 2010 used in this study were collected from secondary sources i.e. Capitaline Corporate Database of Capital Market Publishers (I) Ltd. Mumbai. The data used in this study pertains to the financial year figures of each year under study. Other secondary sources used in this study were CMIE reports, Books, magazines, journals, newspapers, published annual reports of the selected companies, research reports .

\section{(iii) Analysis of data:}

For analyzing the data in this study, simple mathematical tools like percentages, averages, ratios were used. The ratios relating to the measurement of profitability which were used in this study are: (a) Gross profit ratio (GPR), (b) Net profit ratio (NPR), (c) Return on capital employed (ROCE) and (e) Return on net worth (RONW). In order to measure the performance in respect of profitability more precisely a comprehensive rank test considering both average and consistency aspects of the above mentioned indicators of the financial performance was made

\section{Measurement of Profitability of the Selected Companies}

Profitability means the earning capability of a business firm. There are two types of profitability ratios: profit margin ratios and rate of return ratio. Profit margin ratios show the relationship between profit and sales. Since profit can be measured at different stages, there are different types of profit margin ratio. The most popular profit margin ratios are gross profit ratio, net profit ratio, operating profit ratio. Rate of return ratios represent the relationship between profit and investment. The most popular rate of return measures are return on capital employed, return on net worth etc. This chapter presents the analysis of the profitability of the selected companies using the following profitability measures.

\section{Gross Profit Ratio (GPR):}

This ratio shows the margin left after meeting manufacturing costs. It measures the efficiency of production as well as pricing. A high GPR is a sign of good management. Table 1 shows the average GPR of the select companies in Indian cement Industry for the period 2001 to 2010 was 20.19 and its average C.V. for the same period was 58.46 per cent. The study of GPR of the selected companies reveals that six companies, namely, ACC, Ambuja, Chettiland, Madras, Grasim, and Shree maintained their efficiency in production as well as pricing at a level above the industry average (20.19) during the period under study whereas the consistency in respect of efficiency in production as well as pricing was considerably higher in all companies except India, Sanghi and Prism as compared to the industry average (58.46 per cent) during the same period. So, as a whole ACC, Ambuja, Chettiland, Grasim, Madras and Shree had cared or been able to manage their efficiency of production as well as pricing very impressively.

\section{Net Profit Ratio (NPR):}

It shows the earnings left for shareholders (both equity and preference) as a percentage of net sales. It measures the overall efficiency of production, administration, selling, financing, pricing and tax management. Table -2 shows the average NPR of the selected companies in Indian cement industry for the period 2001 to 2010 was 7.94 and its average C.V. for the same period was 128.75 per cent. The study of NPR of the selected companies discloses that five companies, namely, ACC, Ambuja, Birla, Grasim, and Madras maintained their overall efficiency in production, administration, selling, financing, pricing and tax management at a level above the industry average (7.94) during the period under study whereas the consistency in respect of efficiency in production, administration, selling, financing, pricing and tax management was considerably higher in ACC, Amnuja, Birla, Century, Chettiland, Grasim, Madras, OCL, Shree and Sanghi as compared to the industry average (128.75 per cent) during the same period. This conforms that the performance of overall efficiency of production, administration, selling, financing, pricing and tax management of ACC, Ambuja, Birla, Grasim and Madras were encouraging. 


\section{Return on Capital Employed (ROCE):}

This ratio measures the overall profitability of a firm. The higher the ratio, the higher is the overall earning capability of the firm. Table -3 shows the average ROCE of the selected companies in Indian cement industry for the period 2001 to 2010 was 18.03 and its average C.V. for the same period was 63.24 per cent. The study of ROCE of the selected companies reveals that only six companies, namely, ACC, Ambuja, Birla, Grasim, Madras and Prism maintained their overall profitability at a level above the industry average (18.03) during the period under study whereas the consistency in respect of overall profitability was considerably higher in ACC, Ambuja, Century, Grasim, Madras, OCL and Shree as compared to the industry average (63.24 per cent) during the same period. So, as a whole ACC, Ambuja, Grasim and Madras had cared or been able to manage their overall profitability very well.

\section{Return on Net Worth (RONW):}

It measures the earning capability of the company from the view point of its equity shareholders. This ratio expresses the relation of the amount of net profit after tax to the amount of funds invested by the owners. In other words, it indicates how profitably the shareholders' funds have been utilized by the enterprise. Table- 4 shows the average RONW of the selected companies in Indian cement industry for the period 2001 to 2010 was 18.58 percent and its average C.V. for the same period was 89.22 per cent. The study of RONW of the selected companies reveals that only six companies, namely, ACC, Ambuja, Birla, Grasim, Madras and Shree achieved the earning capability from the view point of their owners at a level above the industry average (18.58) during the period under study whereas the consistency in respect of it was considerably higher in ACC, Ambuja, Century, Grasim, Madras and Shree as compared to the industry average (89.22 per cent) during the same period. This confirms that the earning capability of ACC, Ambuja, Grasim, Madras and Shree from the view point of their equity shareholders as a whole was encouraging.

For measuring the profitability status of the selected companies more precisely a comprehensive rank test considering both average and consistency aspects was made. While making such analysis, three steps were undertaken. In the first step comprehensive ranks were ascertained on the basis of the average values of all the selected profitability measures. In this test, a process of ranking was applied to arrive at a more comprehensive measure of profitability in which average values of the selected four ratios, namely, GPR, NPR, ROCE and RONW were combined in a points score. A high average value of any profitability ratio indicates greater profitability and ranking was done in that order. Ultimate ranking was done on the basis of the principle that the lower the aggregate of individual ranks the better is the profitability status and vice versa.

Table 5 shows that Ambuja which ranked first according to the average values of GP,NP, fourth according to the average ROCE and sixth according to the average RONW, had a combined score of 12 in the composite ranking. Similarly, ACC had a combined score of 14, Birla and Grasim15, Shree 17, Madras 18, Prism 26, Chettiland and OCL 34, Sanghi 39, Century 41, and India 47. So, according to the composite score based on the average values of the selected profitability ratios, Ambuja captured the top most position and was followed by ACC, Birla \&Grasim, Shree, Madras, Prism ,Chettiland \& OCL, Sanghi, Century and India respectively in that order.

In the second step the consistency in respect of overall profitability of the selected companies was assessed by using the comprehensive rank test considering C.V. of all the selected profitability ratios of each company during the study period. A low value of C.V. of each selected profitability measure implies a more consistency as well as favourable position in terms of profitability and thus ranking was done in that order. Ultimate ranking was done based on the principle that the lower the aggregate of individual ranks the better is the profitability position and vice versa.

Table 6 reveals that Ambuja which ranked first according to the values of C.V. of GPR \& NPR, third according to the C.V. of ROCE and second according to the C.V. of RONW had a combined score of 7 in the composite ranking. Grasim which ranked first according to the values of CV of ROCE and RONW, second according to the CV of NPR and third according to the CV of GPR had a combined score of 7.SimilarlyOCL 13, Century 17, ACC 21.5, Madras 22, Shree 25.5, Birla 31, Chettiland 39,Sanghi 40,Prism 43 and India. According to the combined score based on the consistency measured by the C.V. of the selected profitability ratios, Ambuja and Grasim both captured the top most position and was followed by OCL, Century, ACC, Madras, Shree, Birla, Chettiland, Sanghi, Prism and India respectively in that order.

In the third step, 'rank based on average' and 'rank based on consistency' for each of the selected companies were added to arrive at its sum of ranks which was ultimately used to ascertain its final profitability rank. Final profitability ranking was done on the principle that the lower the aggregate of 'rank based on average' and 'rank based on consistency', the better is the profitability position and vice versa.

Table 7 shows that Ambuja, which ranked first according to 'average' and jointly first with Grasim according to 'consistency', had a combined score of 2.5 in the sum of ranks. Similarly Grasim had a combined score of 5, ACC 7, both Birla and OCL 11.5, both Shree and Madras 12, Century 15,Chettiland 17.5, Prism 
18,Sanghi 20and India 24. Based on the combined score considering both the average and consistency parameters, Ambuja captured the top most position in respect of earning capability and was followed by Grasim, ACC, both Birla and OCL, both Shree and Madras, Century, Chettiland, Prism, Sanghi and India respectively in that order.

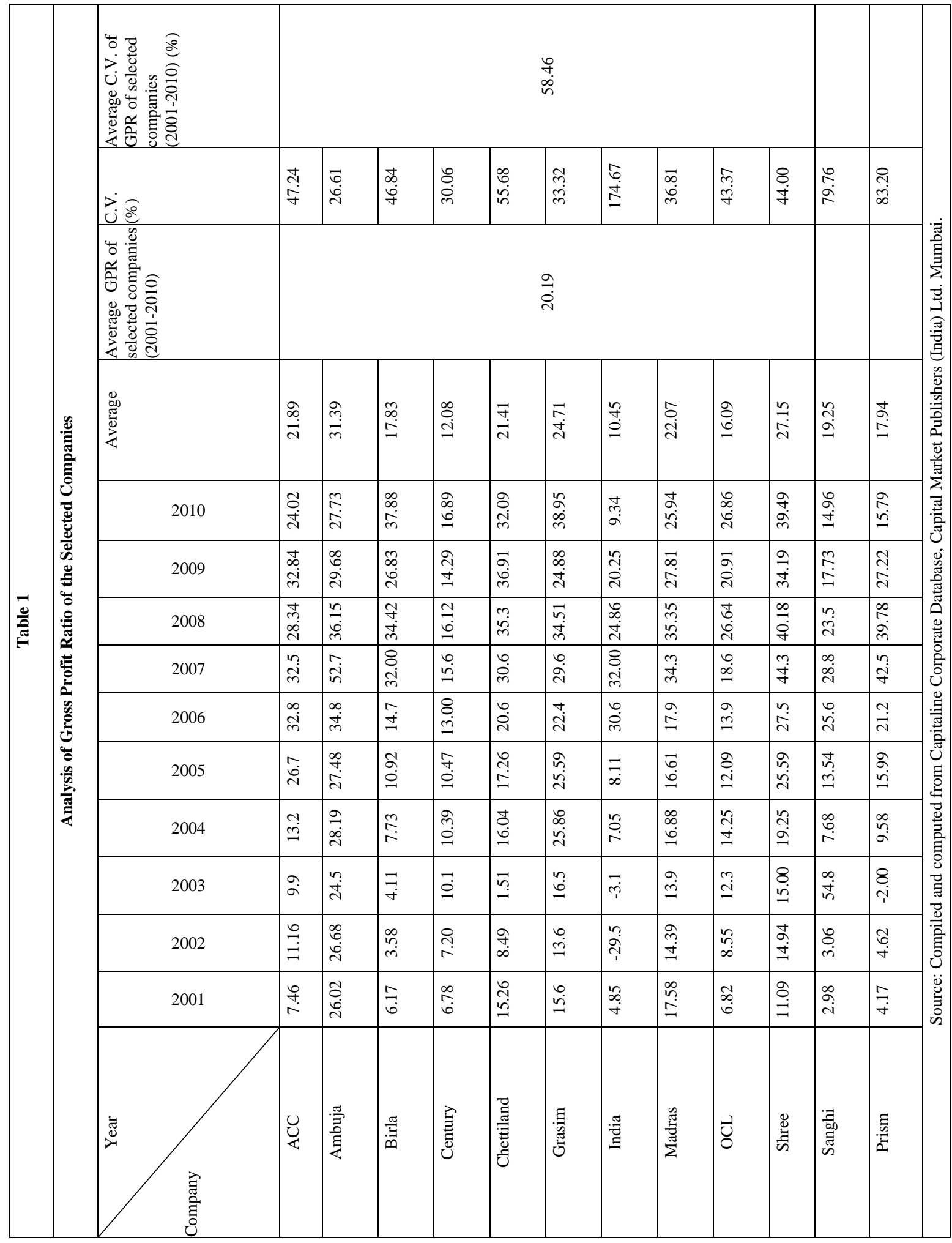




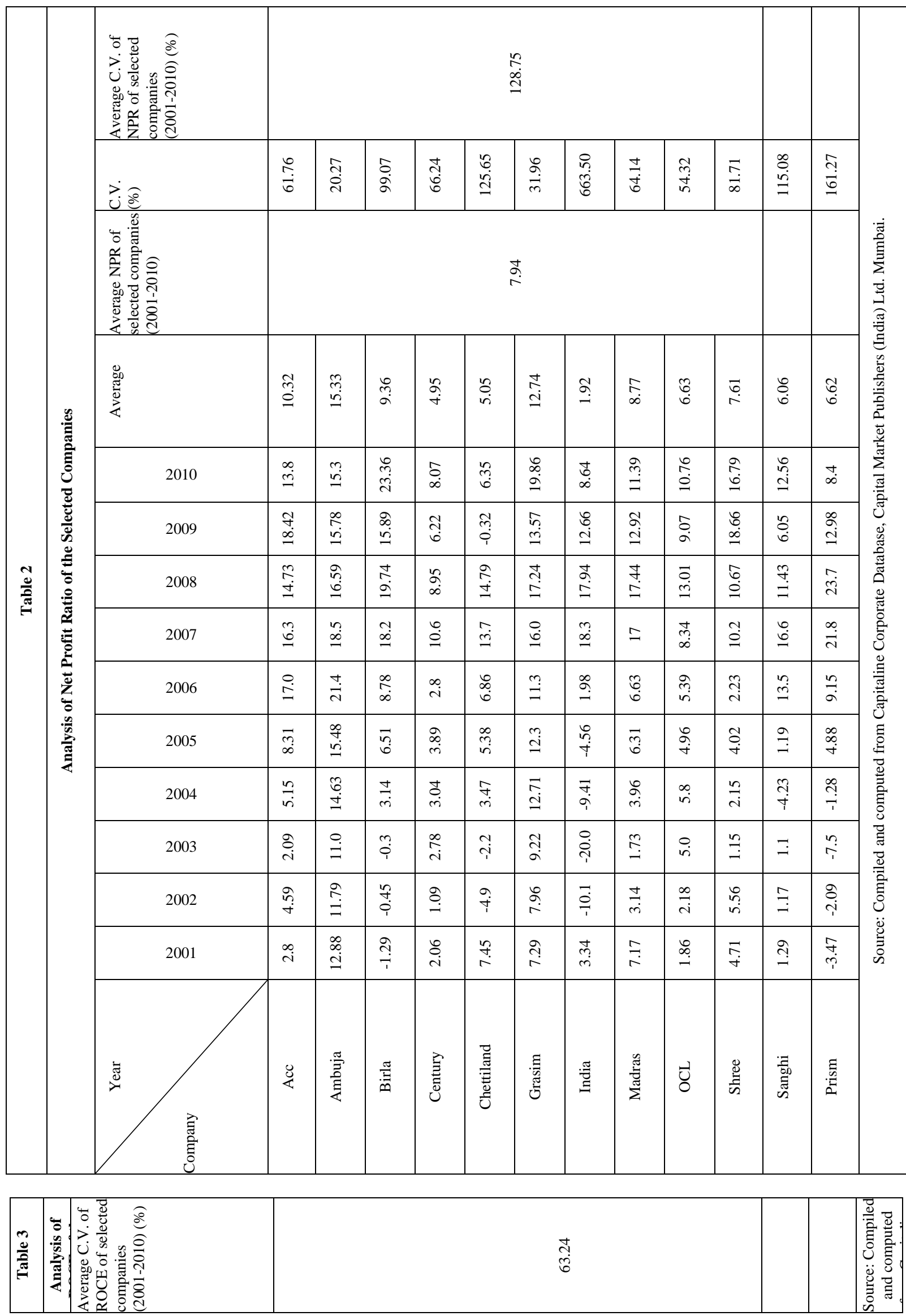




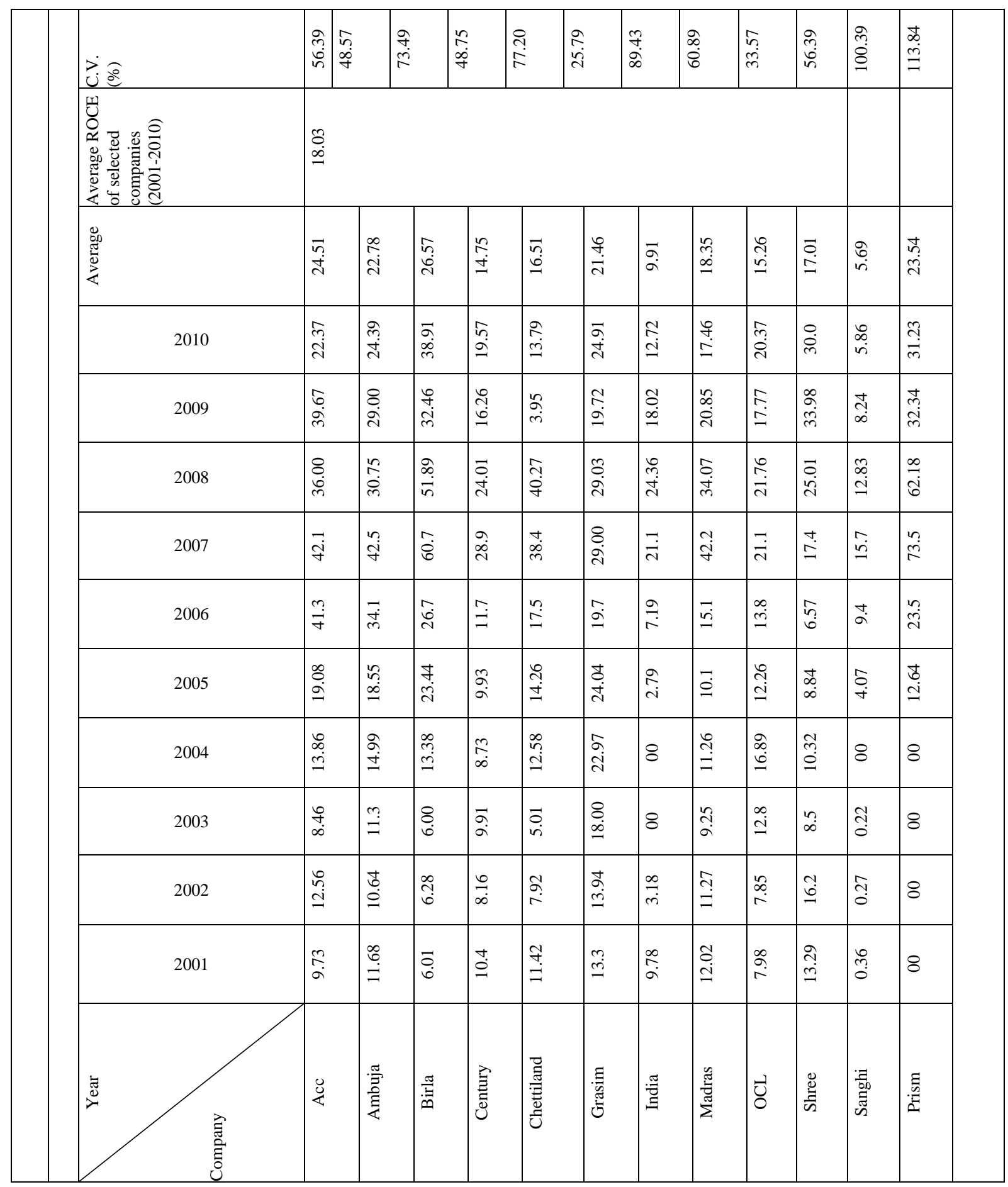

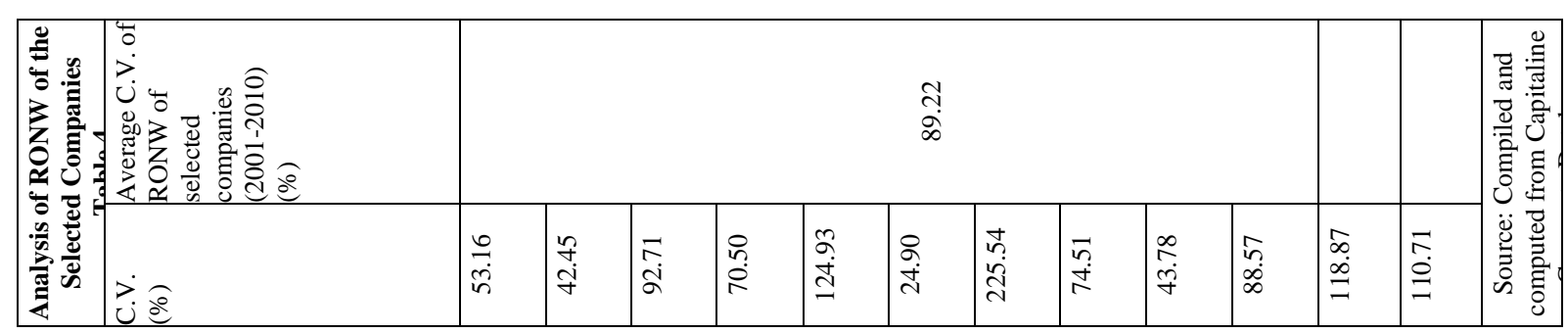




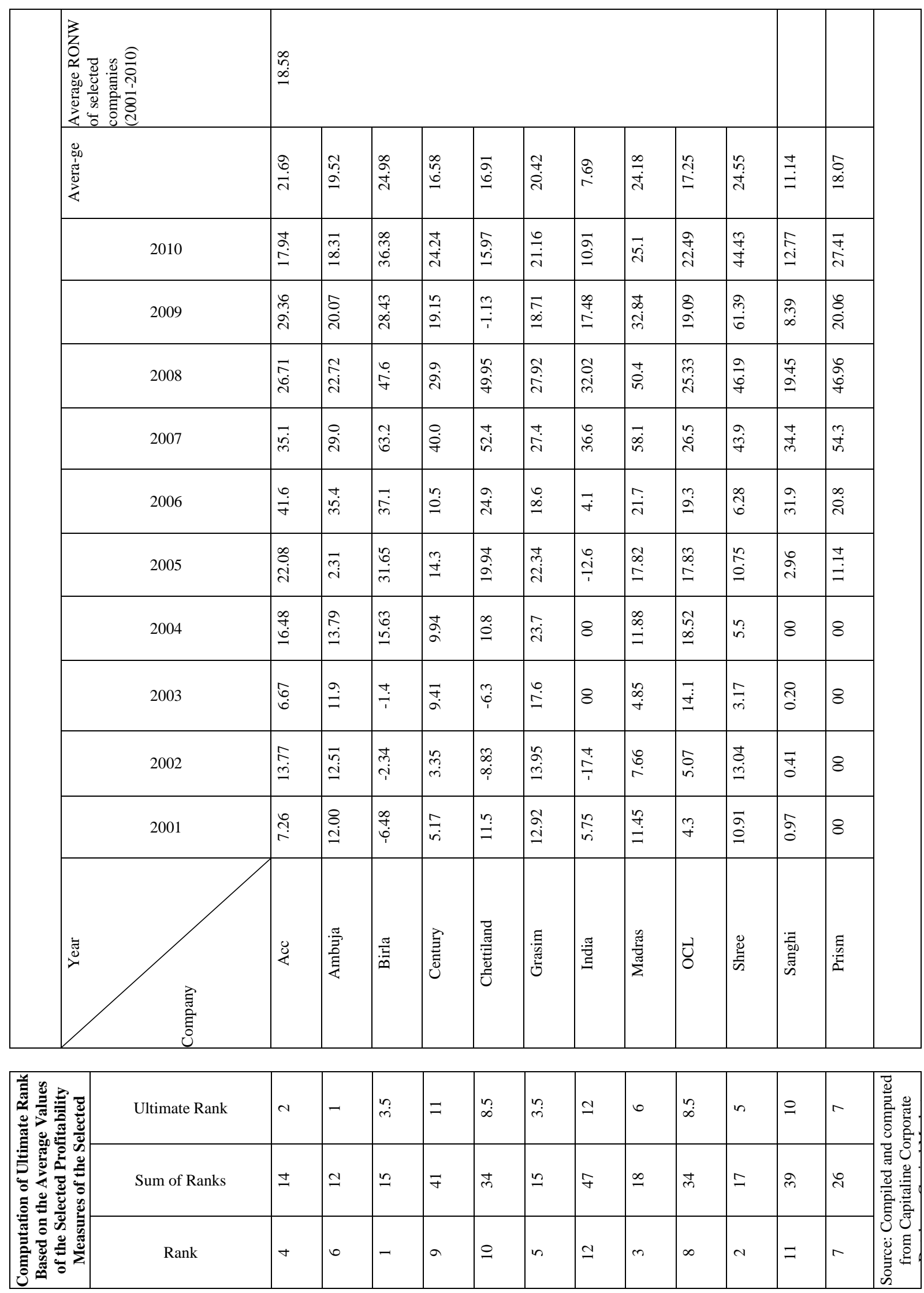




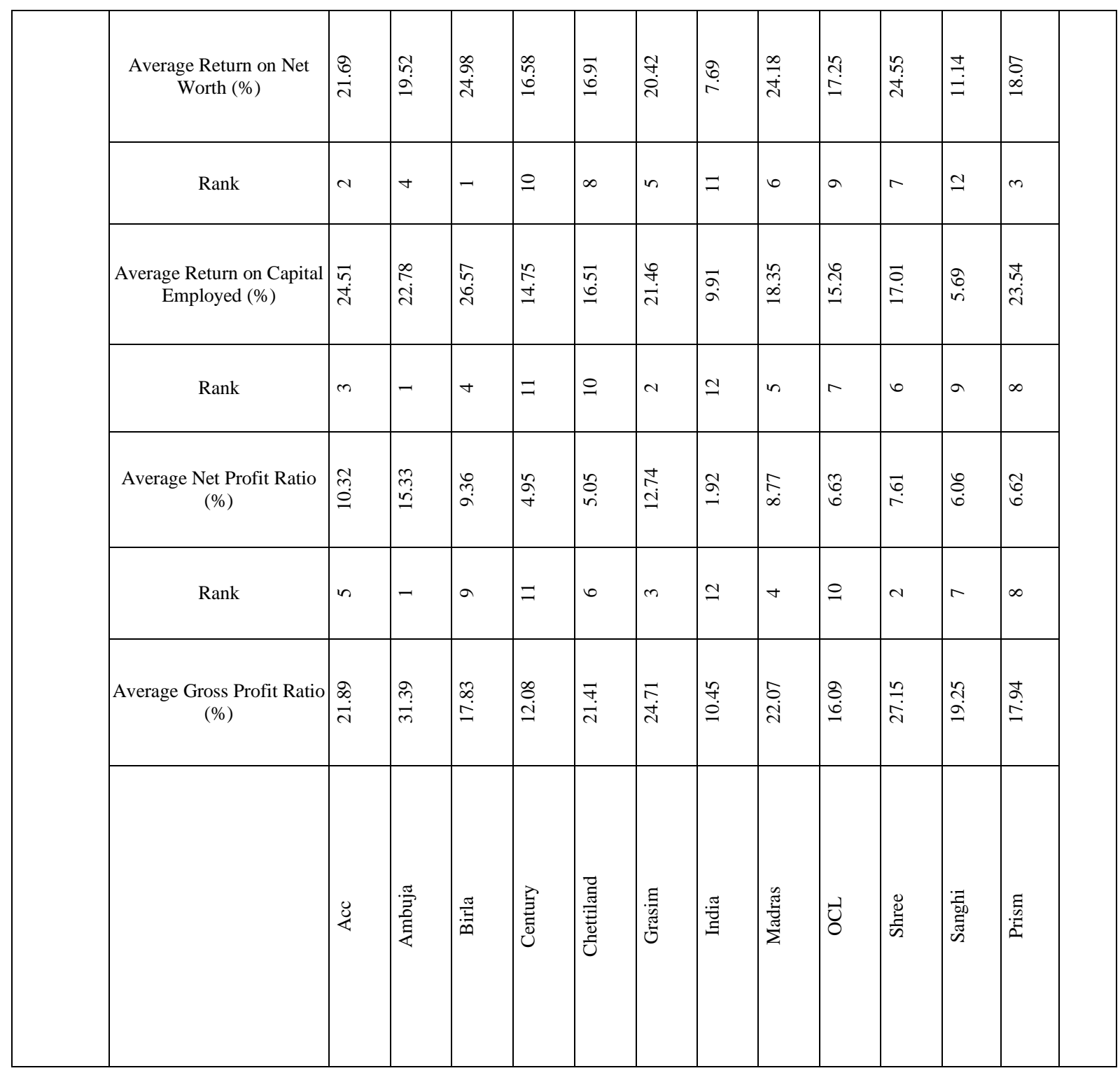

\begin{tabular}{|c|c|c|c|c|c|c|c|c|c|c|c|c|c|c|c|}
\hline \multirow{6}{*}{. } & \multirow{6}{*}{ 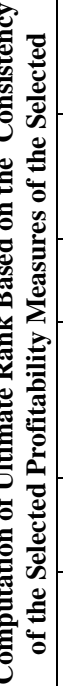 } & Ultimate Rank & n & $\stackrel{n}{-}$ & $\infty$ & $\nabla$ & $a$ & na & $\simeq$ & 0 & $m$ & r & $\cong$ & $\Xi$ & 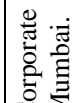 \\
\hline & & Sum of Ranks & $\stackrel{n}{i}$ & r & $\bar{m}$ & 7 & ले & r & o & สิ & 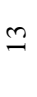 & $\ddot{n}$ & q & q & 悉 \\
\hline & & Rank & t & $\alpha$ & $\infty$ & in & $=$ & - & $\simeq$ & 6 & $m$ & r & $\cong$ & $a$ & \\
\hline & & $\begin{array}{l}\text { Consistency (C.V.) in Return on } \\
\text { Net Worth (\%) }\end{array}$ & $\begin{array}{l}0 \\
\stackrel{0}{\infty} \\
i n\end{array}$ & 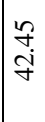 & ì & $\begin{array}{l}\text { iñ } \\
\text { है }\end{array}$ & 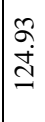 & $\begin{array}{l}8 \\
8 \\
1\end{array}$ & 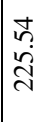 & $\begin{array}{l}\bar{n} \\
+\end{array}$ & $\mid \begin{array}{l}\infty \\
\stackrel{\infty}{\dot{f}}\end{array}$ & $\begin{array}{l}\bar{n} \\
\infty \\
\infty \\
\infty\end{array}$ & $\begin{array}{l}\infty \\
\infty \\
\stackrel{\infty}{=}\end{array}$ & $\begin{array}{l}\stackrel{ }{0} \\
\stackrel{O}{\sigma}\end{array}$ & \\
\hline & & Rank & no & $m$ & $\infty$ & $\nabla$ & $a$ & - & 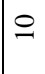 & r & N & in & $=$ & $\simeq$ & \\
\hline & & $\begin{array}{l}\text { Consistency (C.V.) in Return on } \\
\text { Capital Employed (\%) }\end{array}$ & $\begin{array}{l}\text { ले } \\
\text { is } \\
\text { in }\end{array}$ & $\mid \begin{array}{l}\hat{n} \\
\infty \\
\dot{a}\end{array}$ & शे & $\begin{array}{l}2 \\
2 \\
\alpha \\
q \\
q\end{array}$ & & \begin{tabular}{l}
$\hat{\imath}$ \\
\multirow{n}{n}{}
\end{tabular} & $\frac{⿱}{\stackrel{f}{\infty}}$ & $\begin{array}{l}\infty \\
\stackrel{0}{0} \\
\stackrel{0}{2}\end{array}$ & in & $\begin{array}{l}\text { ले } \\
\text { iे }\end{array}$ & 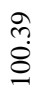 & 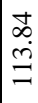 & \\
\hline
\end{tabular}




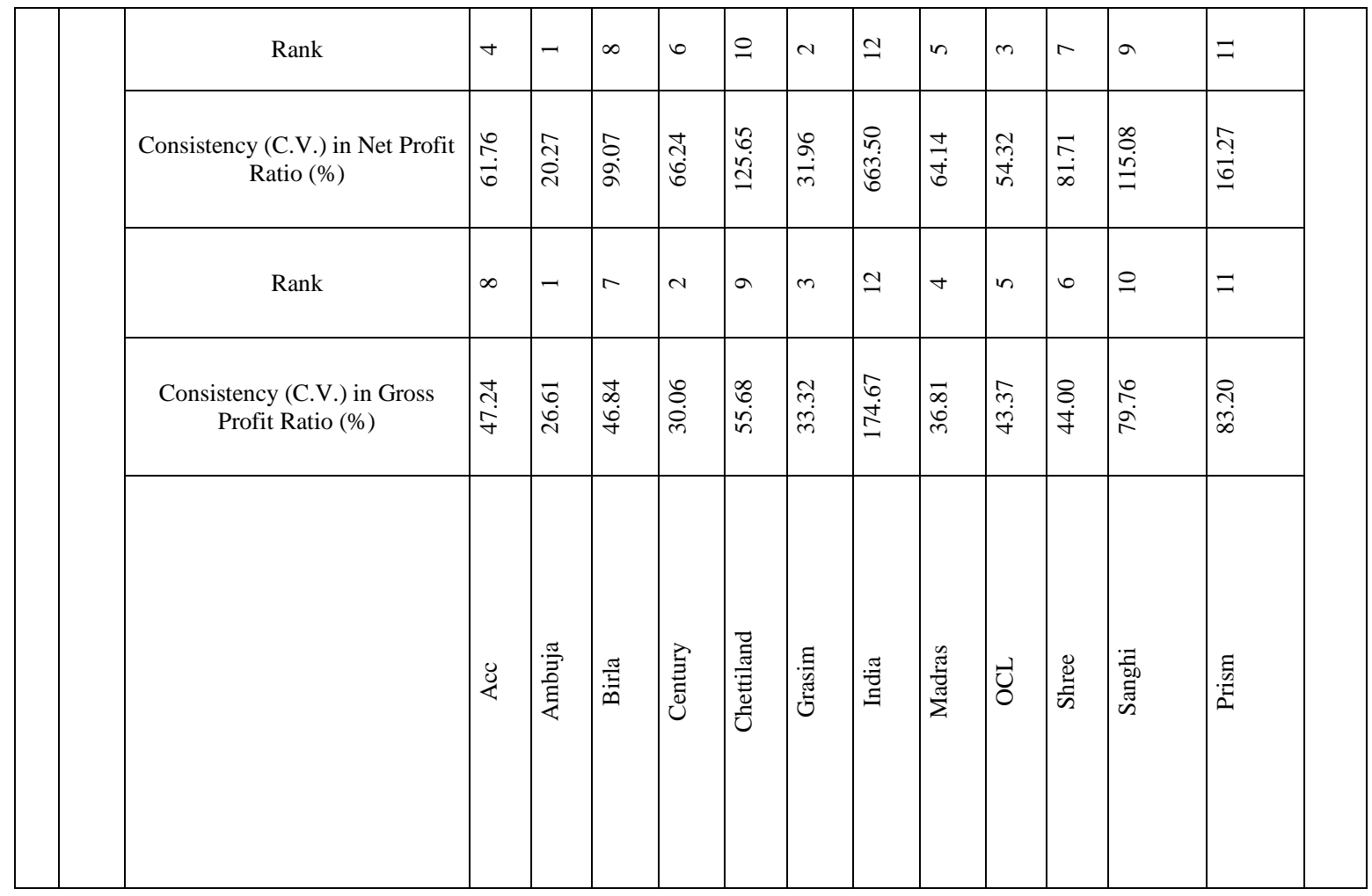

Table 7: Computation of Final Profitability Rank Considering Both the Average and Consistency Parameters of the Selected Profitability Measures of the Selected Companies

\begin{tabular}{|c|c|c|c|c|}
\hline Company & $\begin{array}{c}\text { Ultimate Rank based on } \\
\text { Average }\end{array}$ & $\begin{array}{c}\text { Ultimate Rank based on } \\
\text { Consistency }\end{array}$ & Sum of Ranks & Final Profitability Rank \\
\hline $\mathrm{ACC}$ & 2 & 5 & 7 & 3 \\
\hline Ambuja & 1 & 1.5 & 2.5 & 1 \\
\hline Birla & 3.5 & 8 & 11.5 & 4.5 \\
\hline Century & 11 & 4 & 15 & 8 \\
\hline Chettiland & 8.5 & 9 & 17.5 & 9 \\
\hline Grasim & 3.5 & 1.5 & 5 & 2 \\
\hline India & 12 & 12 & 24 & 12 \\
\hline Madras & 6 & 6 & 12 & 6.5 \\
\hline OCL & 8.5 & 3 & 11.5 & 4.5 \\
\hline Shree & 5 & 7 & 12 & 6.5 \\
\hline Sanghi & 10 & 10 & 20 & 11 \\
\hline Prism & 7 & 11 & 18 & 10 \\
\hline
\end{tabular}

\section{References:}

[1]. Bardia, S.C. (2004): "Liquidity Management: A Case Study of Steel Authority of India Ltd", The Management Accountant, ICWAI, Kolkata, June, pp. 463-467.

[2]. Banerjee, B. (1982): “Corporate Liquidity and Profitability in India”, Research Bulletin, ICWAI, Kolkata, July. Pp. 225-234.

[3]. Basu, S.N. (1992): "Working Capital Management - Tyre Companies" The Management Accountant, Vol. 27, No. 5, Kolkata, p. 332.

[4]. Chakraborty, S.K. (1976): "Funds Flow and Liquidity Management" in Topics in Accounting and Finance, Chakraborty, S.K., Bhattacharya, K..K., Ghosh, S.K. \& Rao, N.K. (ed), Oxford University Press, Kolkata, pp. 81-91.

[5]. Smith, K. (1980): "Profitability Versus Liquidity Tradeoffs in Working Capital Management", in K.V. Smith, Readings on The Management of Working Capital, St. Paul, MN, West Publishing Company, pp. 549-562.

[6]. Sarkar, J.B. \& Saha, S.N. (1987): "Profitability Crisis \& Working Capital Management in the Public Sector in India: A Case Study", The Management Accountant, ICWAI, Kolkata, May, pp. 328-333.

[7]. Shin, H.H. and Soenen, L. (1998): "Efficiency of Working Capital Management and Corporate Profitability", Financial Practice and Education, Fall Winter, pp. 37-45.

[8]. Vijayakumar, A. \& Venkatachalam, A. (1995): "Working Capital and Profitability- An Empirical Analysis", The Management Accountant, ICWAI, Kolkata, June, pp. 748-750.

\section{Books:}

[9]. Pramod Kumar(1991):Analysis of Financial Statements Of Indian Industries:Kanishka Publishing House :Delhi-110031(India)

[10]. G. Purushothamachari\&G. Haranath(2010):Financial performance Of Indian Cement Industry,Madhav Books,Gurgaon(Haryana) 
[11]. Mahesh V. Joshi \&G .Mehta(2006):Globalization And Indian Cement Industry, Adhyayan Publishers\&distributors, New Delhi110002

\section{Journals:}

- GITAM Journal of Management

- Indian Journal of Commerce

- Indian Journal of Accounting

- The Indian Journal of Accounting

- The Indian Journal of Commerce

Thesis: Mr K. Chakraborty (2011)

Financial Performance of Selected Multinational Companies in Indian Pharmaceutical industry During the Post Liberation Era. A Study 